\title{
İlişkisel Pazarlama Bilinirliğinin ve Uygulamalarının Belirlenmesi Üzerine Hizmet Sektörlerinde Nitel Bir Araştırma \\ (Araştırma Makalesi)
}

\section{A Qualitative Research in Service Sectors on Determining Relational Marketing Awareness and Practices}

Doi: 10.29023/alanyaakademik.703212

Davut KARAMAN

Dr. Ögrr. Üyesi Davut KARAMAN, Alanya Alaaddin Keykubat Üniversitesi Alanya Ticaret ve

Sanayi Odası MYO

davut.karaman@alanya.edu.tr

Orcid No: 0000-0001-9097-3460

Bu makaleye atıfta bulunmak için: Karaman, D. (2020). Ilişskisel Pazarlama Bilinirliğinin ve Uygulamalarının Belirlenmesi Üzerine Hizmet Sektörlerinde Nitel Bir Araştırma. Alanya Akademik Bakış, 4(2), Sayfa No..

\section{ÖZET}

Anahtar kelimeler:

İlişkisel Pazarlama, Hizmet Sektörü,

Müşteri

Memnuniyeti,

Müşteri Sadakati

Makale Geliș Tarihi:

13.03.2020

Kabul Tarihi:

25.04.2020

Keywords:

Relational

Marketing, Service

Industry, Customer

Satisfaction,

Customer Loyalty
Araştırmanın amacı hizmet sektöründe faaliyet gösteren işletmeler tarafindan ilişkisel pazarlama bilinirliğinin ve uygulamalarının belirlenmesidir. Bu kapsamda sekiz farkl hizmet alaninda faaliyet gösteren işletme sahipleriyle/yöneticileriyle mülakat yapılmıștır. Araştırma sonucunda katıllmcllara göre müșteri; para, teminat, varoluș nedeni ve gelecek şeklinde ifade edilmektedir. Ilişskisel pazarlama ise müșteri sadakati, memnuniyet, tekrar tercih, işletmenin devamlılı̆̆l, yeni müşteri, başarı, süreklilik, olumlu reklam ve sicak ilişkiyi ifade etmektedir. Mevcut müsterilerini elde tutmak amactyla en fazla uygulanan stratejiler ise ödeme kolaylıkları sunma, iş yeri ziyaretleri yapma, müşteri ihtiyaç analizi yapma, saygl, personel devir hızını düşük tutma, indirim ve kampanya, müşteri ile şeffaf ve sürekli iletişim, kaliteli hizmet sunma, yenilikçi bir anlayış benimseme, kalifiye personel istihdam etme, kurum kültürü oluşturma ve güven olduğu görülmüştür.

\section{ABSTRACT}

The aim of the research is to determine relational marketing awareness and practices by the companies operating in the service sector. In this context, interviews were made with the business owners / managers operating in eight different service areas. According to the participants of the research, the customer; It is expressed as money, collateral, reason for existence and future. Relational marketing refers to customer loyalty, satisfaction, preference, continuity of the business, new customer, success, continuity, positive advertisement and warm relationship. The most applied strategies to retain their existing customers are to offer payment facilities, to visit the workplace, to conduct customer needs analysis, to respect, keep staff turnover low, discount and campaign, transparent and continuous communication with the customer, to provide quality service, an innovative 
understanding adoption, employing qualified personnel, creating corporate culture and trust.

\section{GIRIŞ}

Günümüz bilgi çağında, teknolojik gelişmelerle birlikte hızla gelişen ve değişen çevre, pazarları da etkilemektedir. Pazarda yaşanan yoğun rekabetle birlikte artan belirsizlik, ürünler arasındaki farklılaşmanın azalması ve pazara yeni ürün girişlerinin hız kesmemesi sonucunda birçok işletme yok olmaktadır (Özdemir ve Koçak, 2012: 128). Bu durum ise küreselleşen dünyada her geçen gün artan rekabet ortamında işletmelerin amaçlarına ulaşmasında yeni stratejiler uygulamalarını zorunlu kılmaktadır.

Geleneksel pazarlama faaliyetleri yerini modern pazarlama faaliyetlerine birakmaktadır. Modern pazarlama faaliyetleri ise müşteri odaklı uygulamalarla birlikte müşteri memnuniyeti ve müşteri sadakati üzerine yoğunlaşmaktadır. Bu kapsamda özellikle son yıllarda önemi daha iyi hissedilen modern pazarlama stratejilerinden biri olan müşteri ilişkileri yönetimi ve devamında gelen ilişkisel pazarlama uygulamaları işletmelerin rekabet avantajına ulaşmasında önemli bir role sahiptir (Gülmez ve Kitapçı, 2003: 81).

Müşterilere yeni değerler yaratma ve sunma olarak ifade edilen ilişkisel pazarlama (Kılıç ve Erdoğan, 2016: 461) müşteri memnuniyetini artırarak müşteri sadakatini geliştirmeye yönelik uygulanan stratejik bir yaklaşımdır (Timur, 2003:293).

Son y1llarda gelişmiş ve gelişmekte olan ülkelerde hizmet sektörünün öneminin giderek artması (Yılmaz, 2016: 143) ve müşteri memnuniyeti ile oldukça yakın bir bağı olan ilişkisel pazarlamayı hizmet sektörleri açısından önemli bir konuma getirmektedir. Müşterilerin aldıkları hizmetten ortalama düzeyde bir memnuniyet elde etmeleri işletme ile müşteri arasında uzun süreli bir ilişki oluşturmada yeterli değildir. Ancak aldığ 1 hizmetten "çok memnun" kalan müşteriler, daha sonraki satın alma tercihlerinde aynı işletmeyi tercih etmektedirler (Karaca, 2010: 442). İşgörenlerin saygıll, samimi ve güler yüzlü, pozitif davranışları müşteri memnuniyetini artırmakla birlikte (Soderlund and Rosengren, 2008: 565) müşterinin sadece memnuniyet hissetmesi değil, memnuniyet derecesi müşteri sadakatinin temel belirleyicisi konumundadır. Hizmet sektörlerinde doğrudan müşteri ile ilişki içinde bulunulması hizmet kalitesinin her an ön planda tutulmasını gerektirmektedir.

$\mathrm{Bu}$ çalışma farklı hizmet sektörlerinde faaliyet gösteren işletme sahiplerinin veya üst düzey yöneticilerinin ilişkisel pazarlama konusundaki bilgi düzeylerini, kavram hakkındaki görüşlerini ve bu çerçevede yapmış oldukları uygulamaları belirlemek amacıyla gerçekleştirilmiştir.

\section{2. İLISSTISEL PAZARLAMA}

21.yy'la birlikte gelen değişimler özellikle işletmelerin pazarlama uygulamalarını da etkilemiştir. Alıcı ve satıcı algıları daha fazla ele alınarak çoğulcu bir bakış açısı ile birlikte pazarlamada işlemsel değişimler yerine ilişkisel yönlere odaklanılmıştır (Pels vd., 2000: 11). $\mathrm{Bu}$ odaklanmada işlemsel pazarlamanın kişiselleştirilmemiş ilişkilere dayanması (Grönroos, 1996a: 8) ve çoğunlukla müşterinin gereksinim duyduğu ürünlerin üretilmesi üzerine tesis edilmesi ((Yurdakul, 2007: 269) önemli etkenlerdendir. Bu değişimlerle birlikte işlemsel pazarlamadan, müşteri memnuniyetinin müşteri odaklı yapıldığı (Grönroos, 1994: 12) ve bireyselleştirilmiş kitlesel üretim anlayışının hakim olduğu (Bardakçı, 2004: 3) ilişkisel pazarlamaya geçilmesi gerekmektedir (Kotler, 1992; Gummesson, 1997). 
1990'larda pazarlama literatürüne giren ilişkisel pazarlama kavramı, hizmet kalitesi ve müşteri tatmini literatürüyle yakından ilişkili olmasından dolayı hizmet sektöründe sıklıkla kullanılmaktadır. Ayrıca yapılan çalışmalarda kavram farklı yönleriyle ele alınması nedeniyle literatürde ilişkisel pazarlama kavramına ilişkin çok farklı tanımlamalar mevcuttur (Yürük ve Kayapınar, 2016: 101).

İlişkisel pazarlama kavramını ilk ortaya atan Berry (1983)'ye göre ilişkisel pazarlama "müşterilerle bağları cazip hale getirmek, güçlendirmek ve bu bağları sürdürmektir”. Başka bir ifade ile ilişkisel pazarlama, müşterilerle ve diğer paydaşlarla olan ilişkilerin karşılıklı kazanımla elde edilmesi, kurulması, sürdürülmesi, geliştirilmesi ve gerektiğinde sona erdirilme süreci olarak ifade edilmektedir. Böylece tüm paydaşların amaçları en üst düzeyde gerçekleşmektedir (Grönroos, 1996b).

İlişkisel pazarlama, bir işletmenin pazarlama faaliyetleri içerisinde yer alan tüm müşterileri, tedarikçileri ve varsa diğer paydaşları da dahil ederek sisteme uyumlu hale getirme çalışmalarının bütünüdür (Sheth ve Parvatiyar, 1995). İşletme ile paydaşlar arasında verimli bir ilişki kurulması, sürdürülmesi ve bu ilişkinin geliştirilmesi için uygulanan tüm pazarlama faaliyetleri de ilişkisel pazarlama kapsamında ele alınmaktadır (Morgan ve Hunt, 1994).

Yapılan tanımlamalar ilişkisel pazarlama kavramının tamamen müşteri ile olan bağlantılar üzerine kurulduğunu göstermektedir. İlişkisel pazarlama ile ilgili farklı tanımların "süreklilik, sürdürülebilirlik, karşılıklı kazanımlar, uzun vadeli” gibi ortak yönlerinin olduğu görülmektedir. İlişkisel pazarlama uygulamaları bir işletmenin temel amaçlarına ulaşmasında önemli bir yere sahiptir (Karaman, 2018a: 25-26).

İlişkisel pazarlama kavramını oluşturan unsurların belirlenmesi amacıyla 117 adet kaynaktan yaptığ 1 araştırmada Harker (1999), bu kaynaklarda en çok vurgulanan 26 temel tanım üzerine bir içerik analizi yapmıştır. Analiz sonucunda ilişkisel pazarlama kavramını oluşturan unsurlar yedi temel kategoride toplanmıştır. İlgili araştırma sonucunda oluşturulan yapı Tablo 1'de gösterilmiştir.

Tablo 1. İlișkisel Pazarlamanın 7 Kavramsal Kategorisi

\begin{tabular}{|c|l|l|}
\hline & Birincil (Temel) Yapı & \multicolumn{1}{c|}{ Diğer Ortak Yapılar } \\
\hline $\mathbf{1}$ & Olușturma & Cezbetme, kurma, elde etme \\
\hline $\mathbf{2}$ & Geliştirme & Güçlendirme, iyileștirme, arttırma \\
\hline $\mathbf{3}$ & İdame & Sürdürme, istikrar, koruma \\
\hline $\mathbf{4}$ & Etkileşim & Değişim, karşılıklı, işbirliğine dayalı \\
\hline $\mathbf{5}$ & Uzun dönem & Kalıcı, sürekli, destekli \\
\hline $\mathbf{6}$ & Duygusal içerik & Bağlılık, güven, vaat \\
\hline $\mathbf{7}$ & Çıktı & Kârlı, ödüllendirici, verimli \\
\hline
\end{tabular}

Kaynak: Harker, 1999: 14.

İlişkisel pazarlamada işletme ve paydaşları (müşteri, tedarikçi gibi) arasında ortak amaçlara dayalı bir ilişki söz konusudur. İşletme tarafından uygulanacak cazip uygulamalar ile kurulan ilişkiler neticesinde yeni müşterileri elde edilecektir. Bu ilişkinin güçlendirilmesi ve 
arttırılması sayesinde geliştirilmesi ise istikrarlı ve sürekli müşteri oluşturulmasında önemli etken konumundadır. İşletme ve müşteri arasındaki karşılıklı işbirliğine dayalı (kazan kazan ilişkisi) olumlu etkileşimin uzun dönem devam etmesi ise güvene dayalı bir bağlılık sağlamaktadır. İlişkisel pazarlamanın özünde insan unsurunun yer alması duygusal yapının ihmal edilmemesini gerektirmektedir. Yeni müşterilerin artması ve mevcut müşterilerin de sürekli hale gelmesi işletmenin temel amacı olan verimlilik ve karlılık üzerine olumlu etki sağlamaktadır.

Karlılığa önemli katkısı olan yüksek düzeyde tatmin olmuş müşteri (Priluck, 2003: 37) portföyü sağlamada kullanılan ilişkisel pazarlama; işletmeler açısından müşteri istek ve beklentilerini karşılayarak müşteri memnuniyeti sağlamak (Aydın ve Tavukçu, 2019: 156), müşteriyi elde tutarak yeni müşteriler edinmek (Berry, 2002: 60) ve nihai olarak daha düşük maliyetle daha yüksek karlılık elde etmeyi (İlban, Doğdubay ve Gürsoy, 2009: 123) amaçlamaktadır. Dolayısıyla işletmeler sahadaki pazar payını korumak ve zamanla bu payı artırmayı amaçlamaktadırlar.

Önemli hizmet sektörlerinden biri olan sigortacılık sektörünün gelişmesine rağmen acentelerin pazar payının azalmasını (Karaman ve Şahin, 2019: 173) önlemek için acentelerin müşterilerine yönelik yeni pazarlama stratejilerinin belirlenmesi, acente kaynaklı pazarlama sorunlarının (yetersiz bilgilendirme, nitelikli işgücü vb) güncel olarak tespit edilmesi (Karaman, 2018b) ve ilişkisel pazarlama faaliyetlerinin uygulanması acentelerin pazar payına olumlu katkı sağlayacaktır (Karaman ve Şahin, 2019: 174).

İlişkisel pazarlama kavramı özellikle başta hizmet alanı olmak üzere birçok pazarlama alanına girmiştir. Hizmet işletmelerinde mevcut müşterilerin bağlılığını artırmak ve daha fazla sipariş almak için müşterilerle yakın temasta bulunulma gereksiniminden (Tek, 1999: 51) ve geleneksel pazarlamanın sınırlı olmasından (Gülmez ve Kitapçı, 2003: 82) dolayı ilişkisel pazarlama hizmet sektörlerinde önemli bir gelişme göstermiştir.

İlişkisel pazarlama uzun süreli, sadık müşterilerin daha karlı olduğu varsayımına dayanmasından dolayı (Jesri, Ahmadi ve Fatehipoor, 2013: 307) iliş̧isel pazarlama uygulamalarının işletmeler açısından nihai amacı sürdürülebilir müşteri portföyü oluşturmaktır. Bu kapsamda oluşturulan RETURN modeli ise Şekil 1'de (Karaman, 2019: 209) sunulmuş olup, bu model ile işletmelerin müşterilerini sadık müşteri haline getirmeleri ve yeni müşteri portföyünü daha düşük maliyetle artırmaları amaçlanmaktadır. Modelin ilk çıkış noktası olarak sadık müşteri portföyü oluşturmada mevcut müşterilerin düzenli, sürekli (regular customer) hale gelmesi için müşteri ile doğrudan iletişim halinde olan işgörenlerin (educated person \& quality of service) nitelikli hale getirilmesi gerekmektedir. İşletme ile müşteri arasında köprü olan işgörenlerin nitelikli hizmetleri ile ortaya çıkan ve ilişkisel pazarlamanın temel unsuru olan güvenin (trust \& loyalty) tesis edilmesi, müşterinin eksik ya da yanlış bilgilendirilmesi (unawareness) ile karşılaşacağı olumsuz durumları ortadan kaldırmaktadır. İlişkisel pazarlama kapsamında müşterilere özel uygulamalarla (relationship building \& customer happines) müşterilerinin mutlu olmasını sağlayan işletmeler müşteri sadakati konusunda önemli bir rekabet avantajı elde ederek, sadık müşterileri tarafından çevresine tavsiye edilen bir işletme konumuna gelerek daha hızlı ve daha düşük maliyetle yeni müşteri (new customer) portföyü sağlayabilecektir (Karaman, 2019: 209-212). 


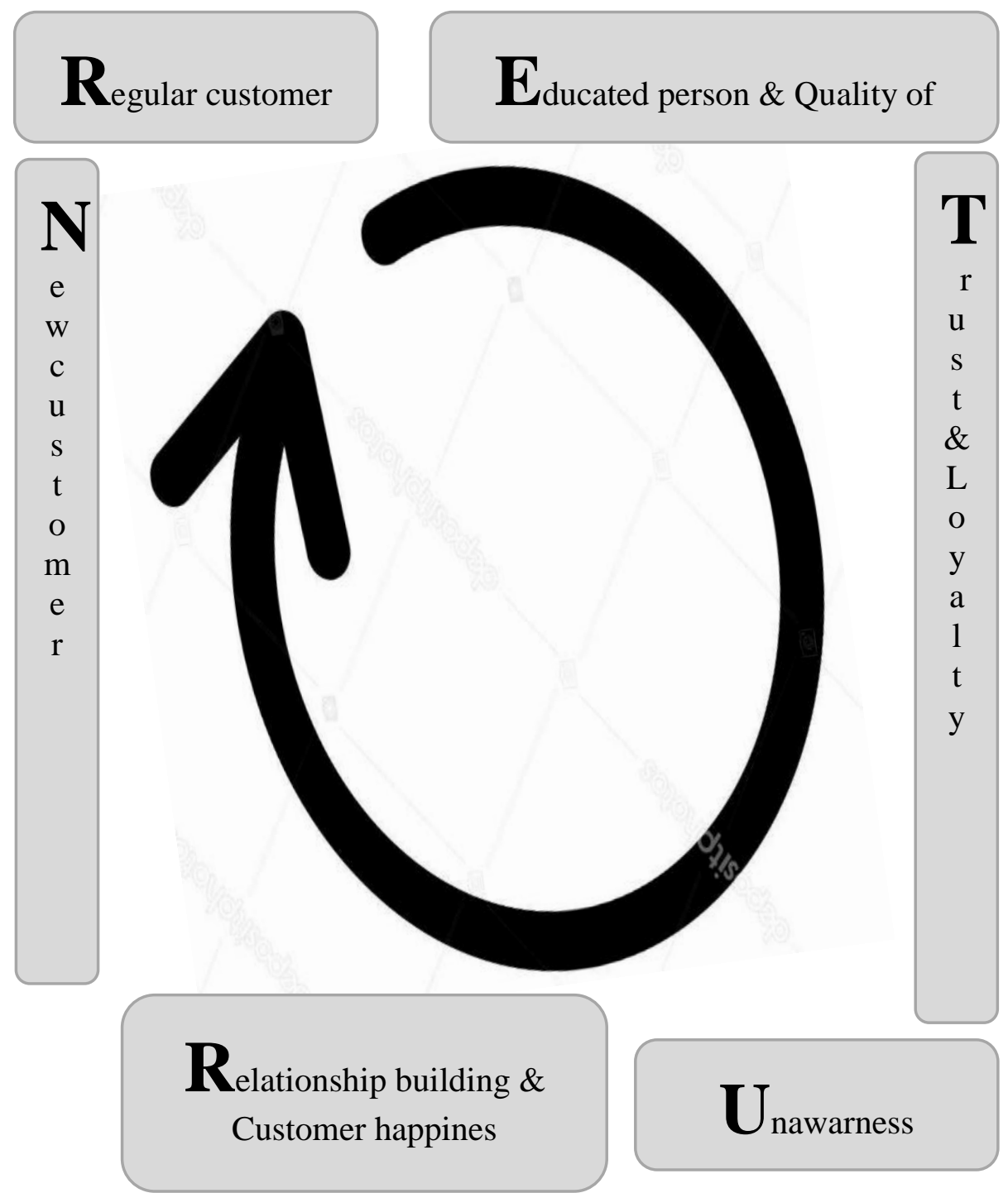

Şekil 1. İlişkisel Pazarlama Ekseninde Sürdürülebilir Müşteri Portföyü Oluşturmada RETURN Modeli

Müşterilerin sadakat düzeyi işletmeler açısından büyük önem taşımaktadır. Bu nedenle müşteri sadakatini etkileyen unsurların işletmeler tarafından bilinmesi ve ona göre müşteri stratejilerinin uygulanması gerekmektedir. Yapılan araştırmalarda müşteri sadakatini belirleyen unsurlar Haciefendioğlu (2005)'na göre “güven, iletişim, tatmin, işbirliği, bağımlılık, empati ve karşılıklılık"; Özyer (2012)'e göre "memnuniyet, güven, algılanan kalite, bağlılık (taahhüt), marka bilinirliği ve ürün katılımı (ilgi)”; Kaur ve Soch (2012)'e göre ise "müşteri memnuniyeti, güven, taahhüt, işletme imajı ve değiştirme maliyeti" şeklinde belirlenmiştir. 
Abdullah ve Kanyan (2012) yaptıkları çalışmada ilişkisel pazarlamanın "güven, bağlılık, iletişim, ortak değerler, empati, sorumluluk, memnuniyet, işbirliği, çatışma yönetimi, güç, firsatçı olmayan davranışlar ve dayanışma" boyutlarının olduğu sonucunu ortaya koymuşlardır (Taşkın vd., 2014: 7).

Gilaninia, Shahi ve Mousavian (2011), ilişkisel pazarlama boyutlarının banka müşterilerinin memnuniyeti ve sadakati üzerindeki etkilerini inceledikleri çalışmada ise ilişkisel pazarlama boyutlarının müşteri memnuniyetini etkilediği ve müşteri memnuniyetinin müşteri sadakati üzerinde etkisi olduğunu ortaya koymuşlardır. Başka bir araştırma sonucuna göre de empati ve güvencenin müşteri memnuniyeti üzerine, müşteri memnuniyetinin de müşteri sadakati üzerine pozitif bir etkisi bulunmaktadır (Kitapçı ve diğerleri, 2013: 239).

Literatürden elde edilen bulgular kapsamında ilişkisel pazarlama uygulamalarının sürdürülebilir müsşteri portföyü oluşturmada önemli olan müşteri sadakati üzerinde olumlu etkileri bulunmaktadır.

\section{METODOLOJI}

$\mathrm{Bu}$ çalı̧̧ma hizmet sektöründe faaliyet gösteren işletme sahiplerinin veya üst düzey yöneticilerinin ilişkisel pazarlama konusundaki bilgi düzeylerini, kavram hakkındaki görüşlerini ve bu çerçevede yapmış oldukları uygulamaları belirlemek amacıyla 15.06.201910.09.2019 tarihleri arasında gerçekleştirilmiştir. Çalışma nitel formda ve olgu bilim desenlemesi ile yapılmıştır. Olgu bilim, günlük hayatta farkında olunan, uygulanan ancak hakkında ayrıntılı bilgi sahibi olunmayan konulara odaklanılması esasına dayanan bir desendir (Yıldırım ve Şimşek, 2005: 72).

Araştırmanın evreni Alanya'da faaliyet gösteren hizmet işletmeleri olarak belirlenmiştir. $\mathrm{Bu}$ kapsamda bankacılık, sigortacılık, turizm, eğitim, sağlık, kuaförlük, hukuk ve muhasebe alanında hizmet vermekte olan kurum ve kuruluşlar araştırma kapsamına alınmıştır. Nitel araştırmalarda örneklem nicel araştırmalara göre daha az sayıda olduğundan, nitel araştırma sonuçlarının genellenmesi güç olmaktadır. İslamoğlu ve Alnıaçık (2013: 208)'a göre nitel araştırmalarda amaç, seçilen örneklemin geniş evrenleri temsil gücüne sahip olması değil, seçilmiş olan örneklemden ölçümlenmek istenilen konu ile ilgili derinlemesine bilgi sağlanabilmesidir.

Araştırmaya konu olan temalar hakkında derinlemesine bilgi toplama olasılığı ise örneklemin kasitlı olarak seçilmesiyle artmaktadır. Bu nedenle çalışmada kasıtlı örnekleme yoluna gidilmiştir. Her bir sektör grubu için alanında en az 10 yıl tecrübeye sahip ve yine en az 10 yıldır faaliyette olan kuruluş sahipleri veya yöneticileri çalışmanın evreni olarak belirlenmiş̧ir. Söz konusu kriterler çerçevesinde mülakat yapılacak olan kişiler seçilmiştir. Sonrasında bu kişilerin yönlendirmesiyle aynı alanda faaliyet gösteren diğer kişilere ulaşılmış ve kartopu örnekleme adı verilen yöntemle çalışma örneklemi genişletilmiştir. Toplamda 8 hizmet alanında 16 kişi ile mülakat gerçekleştirilmiştir.

Mülakat formları yarı yapılandırılmış bir şekilde örnekleme uygulanmıştır. Mülakat formunda yer alan soruların oluşturulmasında O'Malley (2018), Yürük ve Kayapınar (2016), Zhang ve arkadaşları (2016), Erbaşlar (2009) ve Yurdakul ve Dalkılıç (2006)'nın çalışmalarından yararlanılmıştır. Oluşturulan sorular alanında uzman üç kişi tarafından kontrol edilmiş ve mülakat formuna eklenmiştir. Çalışma kapsamında katılımcılara yöneltilen sorular aşağıdaki gibidir: 
- Müşteri/Danışan/Müvekkil/Veli/Hasta kavramları sizin için neyi ifade etmektedir? yapıyorsunuz?

- Mevcut Müşteri/Danışan/Veli/Müvekkillerinizi kaybetmemek için ne tür çalışmalar

- İlişkisel pazarlama kavramını biliyor musunuz?

- İlişkisel pazarlamada önemli olan kavramlar nelerdir?

- İlişkisel pazarlama sizin için neyi ifade etmektedir?

Görüşme sırasında olası veri kayıplarının önüne geçmek amacıyla tüm mülakat süreci katılımcıların izni doğrultusunda ses kayıt cihazı ile kayıt altına alınmıştır. Daha sonra ise veriler dijital ortama aktarılmıştır. Nitel araştırmalarda geçerlilik ve güvenilirlik nicel çalışmalara göre faklı metotlarla test edilmektedir. Guba ve Lincoln (1982), nitel çalışmalarda geçerlilik ve güvenilirliğin yerine inandırıcılığın olması gerektiği görüşünü savunmuştur. Buna göre nitel çalışmalarda inandırıcılığın kriterleri; inanılırlık, onaylanabilirlik, geçerlilik ve aktarılabilirliktir.

$\mathrm{Bu}$ çalışmada verilerin inanılırlığını sağlamak amacıyla kayıt altına alınan ve daha sonra dijital ortama aktarılan veriler katılımcılara teyit ettirilmiştir. Böylece iç geçerliliği sağlama yoluna gidilmiştir. İnandırıcılıkta dış geçerliliği sağlamak için amaçlı örnekleme yapılmış ve alanında uzman olan kişilerle mülakat yapılmıştır. Çalışmanın güvenilirliği ve aktarılabilirliği ise elde edilen sonuçların literatürle uyumuna ve sonuçların evrene genellebilirliğinin kontrolü ile sağlanmıştır. Ayrıca, genellenebilirlik derecesini arttırabilmek adına hizmet sektöründe faaliyet gösteren tek bir işletme veya kurumla değil, sekiz ayrı hizmet sektöründe faaliyet gösteren 16 kurum ve işletme ile uygulama gerçekleştirilmiştir.

\section{ARAŞTIRMANIN BULGULARI}

\subsection{Demografik Veriler}

Araştırma kapsamında mülakat yapılan kişilere ait demografik veriler Tablo 2'de sunulmuştur. Buna göre; katılımcıların turizm, banka, sigortacılık, eğitim, sağlık, kuaförlük, avukatlık ve muhasebe alanlarına dağıldığı görülmektedir. Örneklemde her bir meslek dalından iki kişi yer almaktadır. Eğitim seviyesi ilköğretimden başlayıp, lisansüstüne kadar uzanmaktadır. Toplam 10 katılımcı işletme/kurum sahibi iken, kalan 6 kişi yönetici olarak çalışmaktadır. Örneklemde 8 erkek, 8 kadın katılımcı bulunmaktadır. Erkek katılımcıların 6'sı kendi iş yerinin sahibi iken 2'si yönetici konumundadır. Kadın katılımcıların ise 5'i kendi iş yerinin sahibi iken 3'ü yönetici konumundadır. Katılımcılar içerisinde en düşük mesleki deneyim 10 yıl iken en fazla mesleki deneyim 40'dır. Örnek gurubunda yer alan işletme/kuruluşlardan en yenisi 10 yıldır faaliyette iken en eskisi 48 yıldır faaliyettedir.

Tablo 2. Örneklem Grubuna Yönelik Karakteristik Özellikleri

\begin{tabular}{|c|c|c|c|c|c|c|c|}
\hline Katılımcı & Cinsiyet & Yaş & Eğitim & $\begin{array}{c}\text { Mesleki } \\
\text { Deneyim }\end{array}$ & Statü & $\begin{array}{c}\text { İşletmenin } \\
\text { Faaliyet } \\
\text { Yılı }\end{array}$ & $\begin{array}{c}\text { Faaliyet } \\
\text { Alanı }\end{array}$ \\
\hline K1 & Erkek & 44 & İlköğretim & 20 & Sahibi & 11 & Kuaför \\
\hline K2 & Kadın & 40 & Önlisans & 13 & Sahibi & 10 & Kuaför \\
\hline K3 & Kadın & 36 & Önlisans & 12 & Yönetici & 34 & Banka \\
\hline K4 & Erkek & 30 & Lisans & 10 & Yönetici & 48 & Banka \\
\hline K5 & Erkek & 55 & Lisansüstü & 38 & Sahibi & 26 & Ĕgitim \\
\hline K6 & Kadın & 35 & Lisans & 10 & Yönetici & 14 & Eğitim \\
\hline
\end{tabular}




\begin{tabular}{|c|c|c|c|c|c|c|c|}
\hline K7 & Kadın & 49 & Lisans & 25 & Sahibi & 10 & Turizm \\
\hline K8 & Kadın & 48 & İlköğretim & 27 & Sahibi & 10 & Turizm \\
\hline K9 & Kadın & 47 & Lisansüstü & 23 & Sahibi & 15 & Avukat \\
\hline K10 & Erkek & 48 & Lisans & 26 & Sahibi & 17 & Avukat \\
\hline K11 & Kadın & 33 & Önlisans & 11 & Yönetici & 12 & Sigorta \\
\hline K12 & Erkek & 51 & İlköğretim & 23 & Sahibi & 21 & Sigorta \\
\hline K13 & Erkek & 56 & Önlisans & 27 & Sahibi & 18 & Sağlı \\
\hline K14 & Erkek & 34 & Lise & 11 & Yönetici & 13 & Sağllk \\
\hline K15 & Kadın & 53 & Lise & 32 & Sahibi & 24 & Muhasebe \\
\hline K16 & Erkek & 60 & Lisans & 40 & Yönetici & 35 & Muhasebe \\
\hline
\end{tabular}

\subsection{Araştırma Sorularına Yönelik Bulgular ve Modeller}

\section{- Müşteri/Danışan/Müvekkil kavramları sizin için neyi ifade etmektedir?}

İlişkisel pazarlama faaliyetleri içerisinde en önemli öge müşteridir (Greve ve Schlüschen, 2018). Bu nedenle işletme içerisinde müşteri kavramının ve öneminin iyi bilinmesi gerekmektedir (Luu vd., 2018). Araştırmaya katılan bazı katılımcıların müşterilerini tanımlama şekilleri aşağıda sunulmuştur;

“...Müşteri bizim için kazan-kazan ilişkisini temsil etmektedir. Müşteriler değer gördükleri ve kendilerini önemli hissettikleri yerleri tercih ederler. Böylece hem müşteri kazanır hem de biz kazanırız." (K2)

“...Müvekkiller bizim varoluş sebebimizdir. Onlar olamazsa bizler ayakta duramayız. Bu nedenle müvekkillerimiz bizim için velinimettir.” (K16)

“...Müş̧eri bizim için karşılıklı güven içerisinde kazanç ilişkisini temsil etmektedir. Sürdürülebilir bir kazanç sistemi kurmak için en temel unsurdur. ” (K4)

“...Mă̆duriyete ŭgramış, bu mă̆duriyeti gidermek için tarafimıza başvuran ve hukuki desteğe ihtiyaç duyan herkes bizim için müvekkildir”. (K9)

“...Ruhsal veya bedenen bir rahatsızlı̆̆ bulunan veya rutin kontrol amacıla bize başvuran, kurumumuzun devamı için ihtiyaç duyduğu maddi kaynă̆ı bize sağlayacak olan hasta grubu bizim müşterilerimizi oluşturmaktadır." (K13)

“...Biz ticari dilde müşteri olarak hitap edilen kitleyi velilerimiz olarak adlandırıyoruz. Velilerimiz, sunmakta olduğumuz kaliteli ĕgitim hizmetini belirli bir bedel karşıllı̆ı̆nda almaya hazır olan kişilerdir.” (K6)

“...Bizim için iki tür müşteriden söz etmek mümkündür. Birincisi ulusal ve uluslararası pazarda bizi doğrudan kendi iradesiyle tercih eden bireysel müssterilerdir. Diğeri ise bize toplu olarak müşteri getiren seyahat acentesi ve tur operatörleri gibi aract müşterilerdir. Bunlar, ödemiş oldukları ücret karşılı̆̆ında kaliteli bir hizmet ve rahat bir tatil bekleyen kitleyi ifade etmektedir.” (K8)

“...Müş̧teriler para kazanmamızı sağlayan, işletmemizin varlığını ve geleceğini teminat altına alan, sürekli irtibatta kalmamız gereken kişilerdir.” (K12)

Katılımcılar tarafından müşteri/müvekkil/danışan/hasta/veli kavramlarına verilen cevapların NVİVO programı ile düzenlenmesi sonucu elde edilen model Şekil 2'de verilmiştir. Buna 
göre katılımcıların ifade ettikleri ortak noktalar para, teminat, varoluş ve gelecek başlıkları altında toplanmıştır.

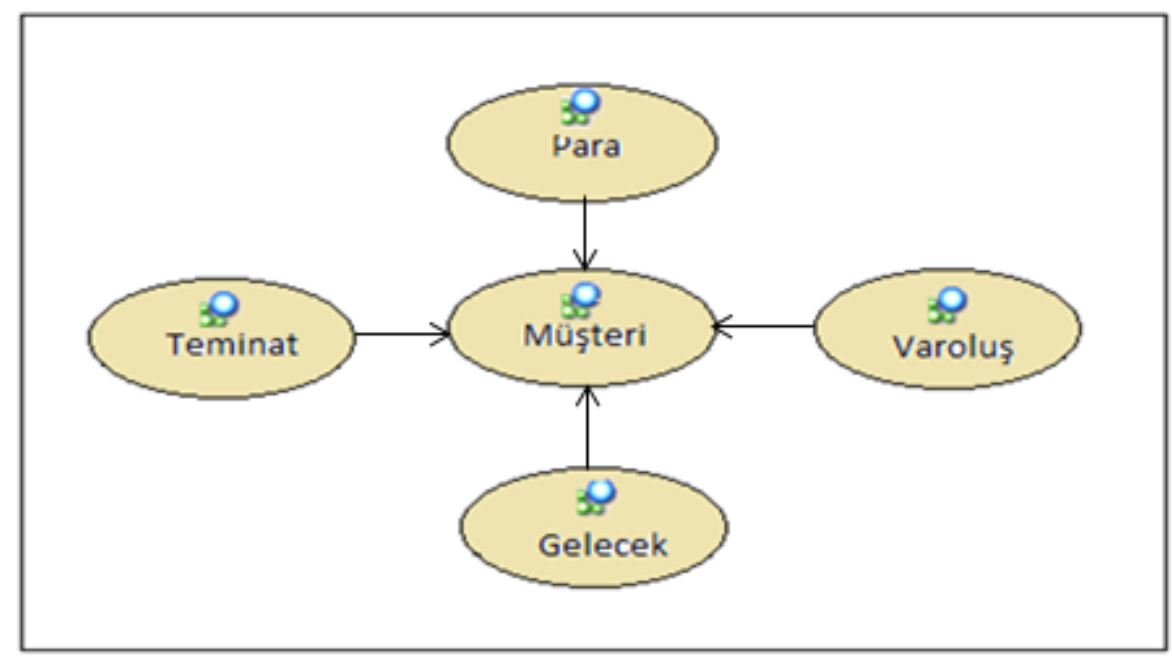

Şekil 2. Müşteri Kavram Modeli

- Mevcut Müşteri/Danışan/Veli/Müvekkillerinizi kaybetmemek için ne tür çalışmalar yapıyorsunuz?

Katılımcıların mevcut müşteri/danışan/veli/müvekkillerini kaybetmemek için neler yaptıklarına ilişkin ifadeler aşağıda verilmiştir.

“...Yerinde ziyaretlerle almış oldukları hizmet hakkında görüşlerini almaktayız. Aynı zamanda ödeme kolaylıkları sunmakta, karşılıklı güven ve saygı çerçevesinde sürekli iletişim sağlamakta ve işimizi özenle yapmaya çalışmaktayız.” (K10)

“...Onların ihtiyaçlarını dinliyor, faydasına veya zararına olan şeyleri açıkça söylüyoruz. Iş̧ yerinde ziyaretlerle yeni ürünlerimizi ve kampanyalarımızı tanıtıyoruz. Müşteri ile irtibat kuracak personelimizi özel eğitimlerden geçiriyoruz. ” (K3)

“...Müşterilerimizi iyi tanımaya çalışlyoruz. Böylece ihtiyaçlarını doğru şekilde belirliyor ve bu çerçevede ürünler sunuyoruz. Fiyat politikalarımızı müşteriye göre belirliyoruz. Müşterilerimize aktif ürünler kullandırmaya çalışıyoruz. ” (K4)

“...Müfredatta ye alan eğitimleri eksiksiz bir şekilde vermeye çalışlyoruz. Kendimizi sürekli yenileyerek güncel kalmaya özen gösteriyoruz. Samimi ve içten davranıyoruz. Verdiğimiz sözleri yerine getiriyoruz.” (K6)

“...Yoğun ilgi alaka gösteriyoruz. Hizmetlerimizde yenilikler yapıyoruz. Indirimlerle tekrar gelmelerinin zeminini hazırlıyoruz. Hoşgörülü olmaya çalışıyoruz. Kaliteli malzemeler kullanıyoruz." (K2)

“...Mevzuatı sürekli takip edip işlerini kolaylaştıracak her bilgiyi anında aktarlyoruz. Aylık rutin ziyaretlerle ilgi ve alaka gösteriyoruz. Karşılıklı ilişkide açık ve net bir iletişim dili kullanıyoruz." (K15) 
“...Fiziki ve teknik koşulları sürekli iyileştiriyoruz. Kaliteli hizmet sunuyor, sosyal projelerde yer almaya çalışıyoruz. Kampanyalar düzenliyoruz. İletişim kanallarımızı açık tutuyoruz. Bilimsel tabanlı hizmet sunuyor ve bunu müşterilerimize anlatıyoruz. ” (K13)

“...Özel günlerinde kutlama mesajları gönderiyoruz. Bazen işimiz olmamasına rağmen ek hizmetler sunarak memnuniyetlerini sağlamaya çalışıyoruz.” (K11)

“...Her yıl hizmetlerimizi ve fiziki koşulları düzenliyoruz. Bunun için yenilikleri yakından takip ediyoruz. Hizmetlerimizi hedef müşteri profiline uygun standartlarda hazlrlyyor ve sunuyoruz. Personel devir hızını düşürmeye çalışlyoruz. Böylece aynı personellerle kurum kültürünü yansıtan slcak bir ortam hazırlamaya çalışıyoruz. İkramlarda bulunuyoruz ve kampanyalar düzenliyoruz." (K8)

Katılımcıların mevcut müşteri/danışan/veli/müvekkil profilini korumak amacıyla yapmış oldukları uygulamalara ilişkin elde edilen model Şekil 3'te sunulmuştur. Katılımcıların mevcut müşterilerini ellerinde tutmak amacıyla izlemiş oldukları stratejiler 14 başlık altında toplanmıştır. Kurum kültürü, güven, ödeme kolaylığı, ziyaret, ihtiyaç analizi, saygı, personelin sürekliliği, indirim, kampanya, açık ve şeffaf iletişim, kaliteli hizmet, yenilikçi anlayış, sürekli iletişim, kalifiye personel katılımcıların izlediği temel müşteri tutma stratejileri olarak ön plana çıkmıştır.

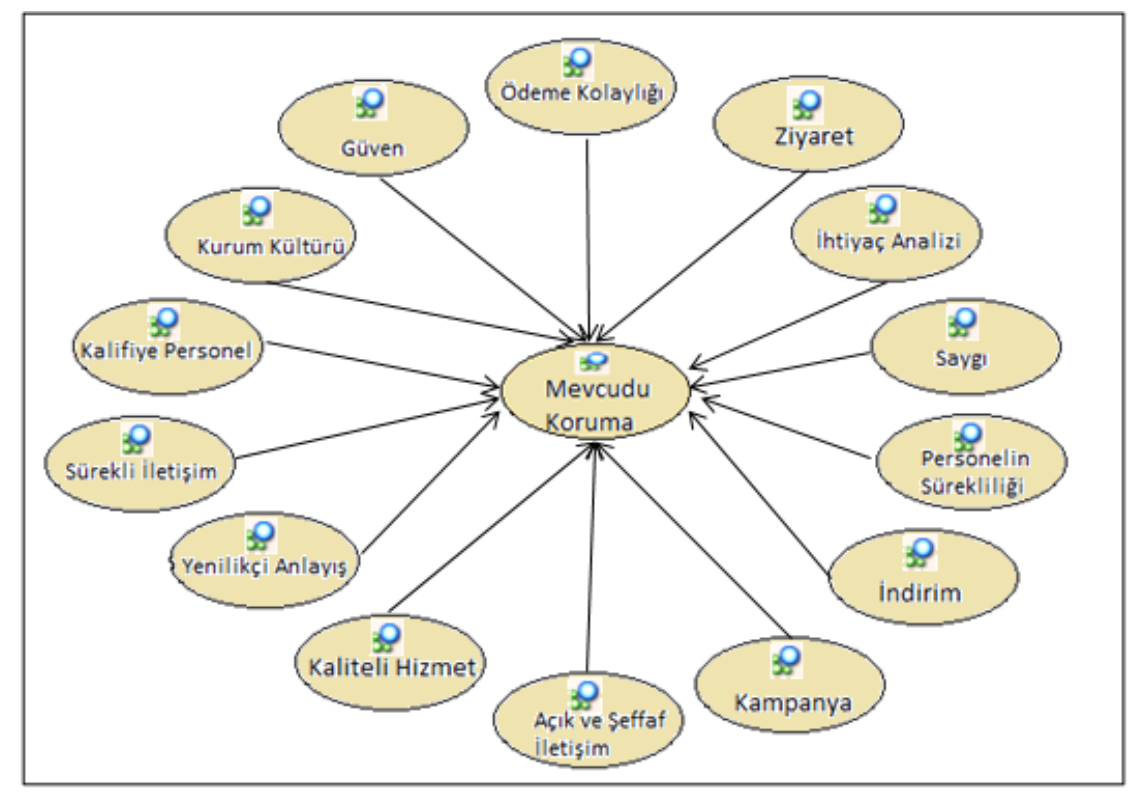

Şekil 3. Katılımcıların Mevcut Müşterileri Elde Tutuma Yöntemleri Modeli

\section{- İlişkisel pazarlamada önemli olan kavramlar nelerdir?}

Katılımcıların ilişkisel pazarlamada önemli gördükleri kavramlara ifadeleri aşağıda yer almaktadir.

“...En başta güven ve sadakattir. Çünkü bu iki kavram ilişki içerisinde olan iki taraf içine en temel değerleri temsil etmektedir.” (K10) 
“...Memnuniyet, güven ve uzmanlıktır. Doğru söylemek güveni, doğru yönlendirme uzmanlı̆̆l temsil eder. Bunların bileşimi müşteri memnuniyetini oluşturur. Sonucunda müşteri işletme ile devam edip etmemeye karar verir.” (K3)

“...Karşıllkll güven ve sadakat önde gelen değerlerdir. Hizmet kalitesi ve kurumsal imajda ilişkisel pazarlama önemli kavramlar olarak değerlendirilebilir.” (K5)

“...Müşteriyi kaybetmeme adına inandırıcılık ve güvence önemlidir. Verilen sözlerin tutulması da müş̧teri ile ilişkide unutulmaması gereken bir değerdir.” (K2)

“...Bizim sektörde uzmanlık ve güven öncelikli kavramlardır. Bunları sağlarsak müşteri sadakatini de oluşturmuş oluruz.” (K16)

“...̈̈ncelikli olarak sağllk sektöründe hastaların size güvenmesi gerekir. Uzman bir kadronuzun olması gerekir. Yüksek kaliteye sahip hizmet sunmanız gerekir. Fiyat politikanızın çok iyi analiz edilmesi gereklidir. Hastaneye gelen kişiler beklentileri karşılanmış mutlu ve sağlıklı birer birey olarak ayrılmalıdır.” (K14)

“...Müşteri herhangi bir sıkıntı yaşadığında yanında olacă̆ımıza ilişkin bize güvenmesi gerekir. Soru sorduğunda aradı̆̆ cevabı verebilecek donanıma sahip uzmanlarla muhatap olmasl gerekir. Sektörümüzle ilgili işlerinde bizi tekrar tercih etmesi için aklında olumlu bir imaj oluşturmamı gerekir. Tabi birde fiyat var.” (K11)

“...Uluslararası bir nitelik taşıyan sektörümüzde müşterilerle olan ilişkilerimizde güven öncelikli konumdadır. Satın alma işlemleri sırasında taahhüt edilenlerin sunulması, işinde uzman kişilerden hizmet almaları, ülke ve işletme imajı da ilişkisel pazarlama da önemli diğer unsurlardır diyebilirim." (K9)

Katılımcıların vermiş oldukları cevaplarda üzerinde önemle durdukları kavramlar güven, sadakat, fiyat, uzmanlık, iletişim, imaj, hizmet kalitesi, memnuniyet ve taahhüt olarak belirlenmiştir. Bu kavramlara yönelik modelleme Şekil 4’te verilmiştir.

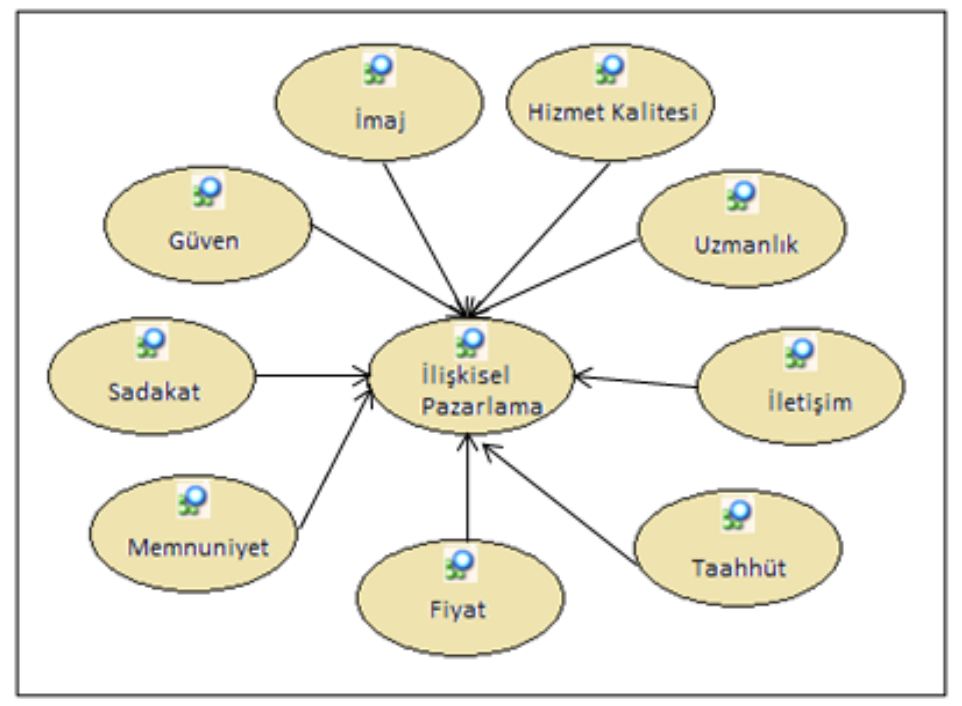

Şekil 4. İlişkisel Pazarlamada Önemli Kavramlar 


\section{KARAMAN}

\section{- İlişkisel pazarlama sizin için neyi ifade etmektedir?}

Katılımcıların ilişkisel pazarlamaya yönelik düşüncelerini içeren ifadelerine aşağıda yer verilmiştir.

“...Müvekkillerin her hukuki işinde bizi tercih etmesini sağlayacak önemli değerler bütünü olarak görüyorum. İlişkisel pazarlama faaliyetleriyle onların memnuniyetini sağlamak daha kolay oluyor." (K10)

“...Müş̧terilerimizin memnuniyetini ve sürekliliğini ifade ediyor. Kurumumuz açısından olumlu reklamı ve bu yolla yeni müsteriler kazanmayı ifade ediyor.” (K3)

“...Illişkisel pazarlama müşterilerle daha iyi, daha yakın ve sıcak ilişkileri temsil eden bir pazarlama aracıdır. Bu sayede müşterilerimizin memnuniyet oranını arttırabiliyoruz. Tutundurma faaliyetlerimizi daha kolay bir şekilde başarıya ulaştırabiliyoruz. Müşterilerimizi kurumumuzda sabitleyebiliyoruz. Bu sayede bizlerde uzun vadeli kararlarl rahatlikla alıp yeni yatırımlar yapabiliyoruz." (K4)

“...Velilerimizi memnun etmenin kisa ve en etkili yolu diyebilirim. Ayrlca olumlu reklam açısından da önemli görüyorum. ”(K5)

“...Müşteri istikrarını arttırmayı ifade ediyor. Sürekli değişmeyen sabit bir kazancın işletmemde kalmasının önemli bir yolu. Bu işletmemin yaşaması için çok önemlidir.” (K1)

“...Illk aklıma gelen şey müşteri devamlılı̆̆ oldu. Çünkü biz ilişkisel pazarlama çerçevesindeki tüm faaliyetleri bunun için yapıyoruz. Sonuçta müşteri bizi tercih ettiği sürece varız. Bunun yanında yeni müşteriler kazandı̆̆ımız sürece de büyümek mümkün.” (K15)

“...Müşteri ile iyi ilişkileri ve güveni temsil ediyor. Hastalarımızın bizi tekrar tercih etmesi ve reklamımızı yapması için bir firsat olduğunu söyleyebilirim.” (K13)

“...Işs kalitesi, süreklilik ve kaliteli hizmet. Sabit getiri ve sonucunda az risk. Benim için kavramın temsil ettiği de ğerler bunlardır.” (K12)

“...Müşterilerin sürekliliğini sağlamada çok önemli bir faktör olarak değerlendiriyorum. Özellikle müşteri memnuniyetini oluşturma adına önemli kavramlar bünyesinde barındıran bir pazarlama türü. Müşterilerin memnun olması bizim için önemli bir referans kaynă̆ıdır. Çünkü memnun olan müşteriler tekrar gelme eğiliminde olduğu gibi kendileriyle beraber olumlu ă̆ızdan ă̆ıza reklam yoluyla yeni müşterilerinde bizi tercih etmesini sağlamaktadır. " (K7)

Şekil 5'te görüldüğü üzere katılımcıların ilişkisel pazarlama kavramına yüklediği değerler sekiz tema altında toplanmıştır. Bunlar; müşteri sadakati, memnuniyet, tekrar tercih, işletmenin devamlılığı, yeni müşteri, başarı, süreklilik, olumlu reklam ve sıcak ilişkidir. 


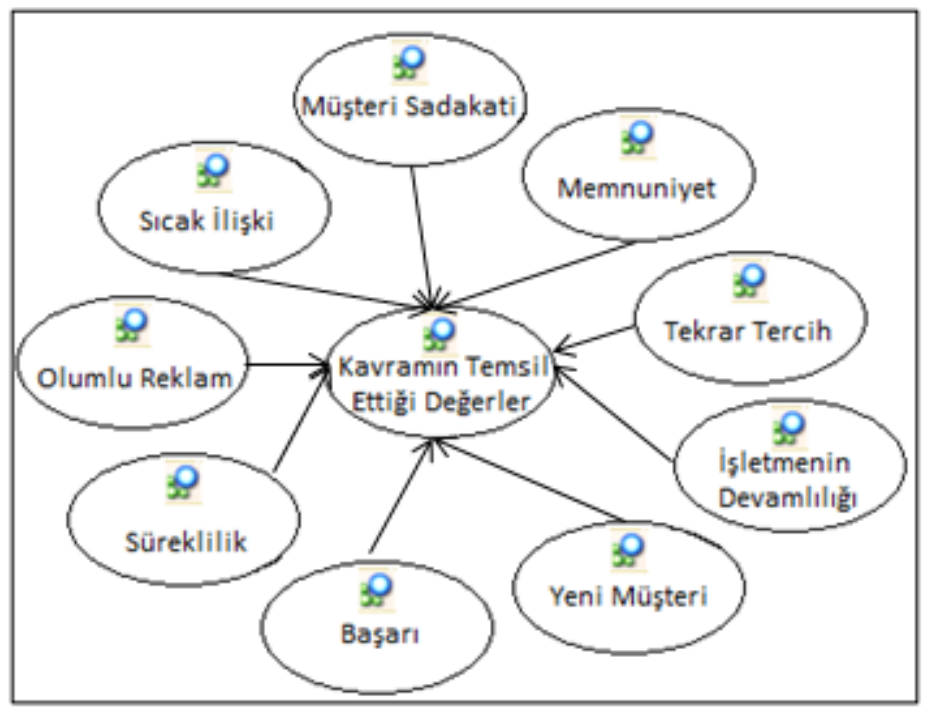

Şekil 5. İlişkisel Pazarlamanın Temsil Ettiği Değerler

\section{SONUÇ}

Yapılmış olan bu çalışma ile hizmet sektöründe faaliyet gösteren işletme kurum sahibi veya yöneticilerinin ilişkisel pazarlama kavramı hakkındaki bilgileri derinlemesine ölçümlenmeye çalışılmıştır. Bu kapsamda sekiz farklı hizmet alanında faaliyet gösteren kurum ve işletme sahipleriyle/yöneticileriyle mülakat yapılmıştır.

Çalışma sonucunda katılımcıların müşterilerini para, teminat, varoluş nedeni ve gelecek kavramlarıyla eşleştirdiği belirlenmiştir. Hali hazırda müşteri/tüketici kavramının tanımı da bu kavramları doğrudan veya dolaylı olarak bünyesinde barındırmaktadır. Durmaz (2006: 56) müşteri/tüketiciyi tanımlarken "kendisi veya ailesi için mal ve hizmet alıp tüketen veya kullanan kişidir" ifadesini kullanmıştır. Mal ve hizmet alımında kullanılan temel araç ise paradır. Para işletmelerinin temel girdilerinden birisini oluşturmaktadır. $\mathrm{Bu}$ nedenle para işletmelerin varlığını sürdürebilmelerinin en önemli teminatlarındandır.

Katılımcıların mevcut müşterilerini korumak amacıyla izledikleri stratejiler değerlendirildiğinde en fazla kullanılan kavramların ödeme kolaylıkları sunma (Thakur ve Srivastava, 2014), iş yeri ziyaretleri yapma (Gill vd., 2007), müşteri ihtiyaç analizi yapma (Song vd., 2018), saygı (Cardador ve Pratt, 2018), personel devir hızını düşük tutma, indirim ve kampanya (Zhu vd., 2019), müşteri ile açık ve şeffaf bir iletişim (Skoumpopoulou ve Franklin, 2019) kaliteli hizmet sunma (Ju vd., 2019), yenilikçi bir anlayış benimseme (Wikhamn, 2019), müşteri ile sürekli iletişim halinde kalma (Soteriou ve Chase, 1998), kalifiye personel istihdam etme (Darzi ve Bhat, 2018), kurum kültürü oluşsturma çabaları ve güven (Blut vd., 2015) olduğu görülmüştür.

Katılımcıların ilişkisel pazarlama sürecinde önemli gördükleri kavramlar hizmet kalitesi (Harun vd., 2018; Luu vd., 2018), imaj (Sheth ve Parvatlyar, 1995), uzmanlık (Copulsky ve Wolf, 1990), güven (Baran ve Taşkın, 2015), sadakat (Basalamah vd., 2018), memnuniyet 
(Susskind vd., 2018), fiyat (Grönroos, 1997), taahhüt (Fyall vd., 2003) ve iletişim (Grönroos, 2004) olarak elde edilmiştir.

Katılımcıların ilişkisel pazarlamanın kendileri için neyi ifade ettiğine yönelik cevapları değerlendirildiğinde, kavrama bakış açılarının dokuz temel değer etrafında toplandığı görülmüştür. Bunlar müşteri sadakati (Oly Ndubisi, 2007; Gaurav, 2016; Basalamah, 2018), memnuniyet (Leverin ve Liliander, 2006), tekrar tercih (Ha vd., 2010), işletmenin devamlılığı, yeni müşteri (Palmatier ve Steinhoff, 2019), başarı (Morgan ve Hunt, 1994), süreklilik (Palmatier vd., 2006), olumlu reklam (Enyinda vd., 2018) ve sıcak ilişkidir (Karim, 2018).

Derinlemesine görüşmeler aracılığıyla elde edilen görüşme formlarının değerlendirilmesiyle ulaşılan sonuçların literatürle son derece uyumlu olduğu görülmüştür. Bu durum örneklem grubunda yer alan katılımcıların ilişkisel pazarlama faaliyetlerini hali hazırda kullandıklarını ortaya koymuştur. Özellikle bankacılık, sigortacılık, sağlık ve turizm sektöründe faaliyet gösteren işletme/kurum yetkililerin verdikleri cevaplar ilişkisel pazarlamanın doğası ile tamamen uyumludur. Kuaförlük, muhasebe, avukatlık, eğitim alanlarında faaliyet gösteren kurum/işletme temsilcilerinin verdikleri cevaplar ise doğrudan olmasa bile dolaylı olarak ilişkisel pazarlama uygulamalarıyla ilişkilidir. Bir değerlendirme yapmak gerekirse, bankacılık, sigortacılık, sağlık ve turizm gibi kitlesel müşteri gruplarına hizmet veren ve kurumsallık derecesi diğer hizmet kurumlarına göre daha yüksek olan sektörlerde ilişkisel pazarlama faaliyetlerinin daha bilinçli bir şekilde kullanıldığını söylemek yanlış olmayacaktır.

Çalışmanın farklı örneklemlerde tekrarlanması ve sonuçların karşılaştırılması genel bir değerlendirme yapma adına önem taşımaktadır. Ayrıca, çalışmanın tekrarlanması hizmet sektörü için genel bir değerlendirme yapmayı da mümkün kılacaktır.

\section{KAYNAKÇA}

AYDIN, S., TAVUKÇU, A. (2019), İlişkisel Pazarlama Uygulamalarının Müşteri Sadakati, Müşteri Memnuniyeti ve Müşterilerin Tavsiye Etme Eğilimi Üzerine Etkisi: Türk Katılım Bankacılığı Sektöründe Bir Araştırma, Proceedings of the International Congress on Business and Marketing, Maltepe University, Istanbul.

BARAN, A., TAŞKIN, E. (2015). "Güven, İletişim ve Empati Bağlamında İlişkisel Pazarlamanın Tüketici Temelli Marka Değerine Etkisi: Gsm Operatör Kullanıcıları Üzerinde Bir Uygulama". International Journal of Social Sciences and Education Research, Cilt.3, Sayı.2, 361-378.

BARDAKÇI, A. (2004). “Kitlesel Bireyselleştirme Uygulama Yöntemleri”, Akdeniz İ.İ.B.F. Dergisi Sayı:8, 1-17.

BASALAMAH, M. R., MOELJADI, M., SUNARYO, S., \& SUDJATNO, S. (2018). "The Effect of Service Quality And Relationship Marketing Towards Customer Loyalty for Sharia Banking (Sharia Banking Study in Makassar Indonesia)". International Review of Management and Marketing, volume.8, Isuue.1, 107-114.

BERRY, L.L (2002). "Relationship Marketing of Services- Perspectives from 1983 and 2000”, Journal of Relationship Marketing, Vol. 1(1), 59-77. 
BERRY, L.L., (1983), Relationship Marketing, in Emerging Perspectives on Services Marketing eds. Berry, L.L, Shostack, G.Land Upah, G.D., eds, American Marketing Association, Chicago.

BLUT, M., FRENNEA, C. M., MitTAL, V., \& MOTHERSBAUGH, D. L. (2015). "How Procedural, Financial and Relational Switching Costs Affect Customer Satisfaction, Repurchase Intentions, and Repurchase Behavior: A meta-analysis". International Journal of Research in Marketing, 32(2), 226-229.

CARDADOR, M. T., \& PRATT, M. G. (2018). "Becoming Who We Serve: A Model of Multi-Layered Employee-Customer Identification". Academy of Management Journal, volume.61, Issue.6, 2053-2080.

COPULSKY, J. R., \& WOLF, M. J. (1990). "Relationship Marketing: Positioning for the Future". Journal of Business Strategy, volume.11, Issue.4, 16-20.

DARZI, M. A., \& BHAT, S. A. (2018). "Personnel Capability and Customer Satisfaction as Predictors of Customer Retention in the Banking Sector: A Mediated-Moderation Study". International Journal of Bank Marketing, Volume. 36 Issue. 4, 663-679.

DURMAZ, Y., (2006). "Modern Pazarlamada Tüketici Memnuniyeti ve Evrensel Tüketici Hakları", Journal of Yasar University, Cilt.1, Sayı.3, 255-266.

ENYINDA, C. I., OGBUEHI, A. O., \& MBAH, C. H. (2018). "Building Pharmaceutical Relationship Marketing and Social Media Impact: An Empirical Analysis". International Journal of Pharmaceutical and Healthcare Marketing, Volume.12, Issue.2, 198-230.

ERBAŞLAR, G., (2009). “İşletmelerde İlişki Pazarlaması”, Paradoks, Ekonomi, Sosyoloji ve Politika Dergisi, C.5(2).

FYALL, A., CALlOD, C., \& EDWARDS, B. (2003). "Relationship Marketing: The Challenge for Destinations". Annals of tourism research, volume.30, Isuue.3, 644-659.

GAURAV, K. (2016). "Impact of Relationship Marketing on Customer Loyalty: Evidence from Indian Automobile Industry”. Purushartha: A Journal of Management Ethics and Spirituality, Volume.9, Issue.1.

GILANINIA, S, SHAHI, H., MOUSAVIAN, S. J (2011) "The Effect of Relationship Marketing Dimensions by Customer Satisfaction to Customer Loyalty" Interdisciplinary Journal of Contemporary Research in Business Vol 3, No: 4, 74-84.

GILL, D., BYSLMA, B., \& OUSCHAN, R. (2007). "Customer Perceived Value in a Cellar Door Visit: The Impact on Behavioural Intentions". International Journal of Wine Business Research, 19(4), 257-275.

GREVE, G., \& SCHLÜSCHEN, A. (2018). From Customer Relationship Management to Influencer Relationship Management. In Diverse Methods in Customer Relationship Marketing and Management, IGI Global, 80-91. 
GRÖNROOS, C. (1994). "From Marketing Mix To Relationship Marketing: Towards A Paradigm Shift In Marketing.” Management Decision, vol. 32(2), pp. 4-20.

GRÖNROOS, C. (1996a), "Relationship Marketing Logic" Asia-Australia Marketing Journal, 4, No. 1 , pp. 7-18.

GRÖNROOS, C. (1996b). "Relationship Marketing: Strategic And Tactical Implications", Management Decision, Vol. 34 Iss: 3 pp. 5 - 14.

GRÖNROOS, C. (1997). "Keynote Paper From Marketing Mix to Relationship MarketingTowards a Paradigm Shift in Marketing”. Management Decision, volume.35, Issue.4, 322-339.

GRÖNROOS, C. (2004). "The Relationship Marketing Process: Communication, Interaction, Dialogue, Value”. Journal of Business \& Industrial marketing, volüme.19, Issue.2, 99113.

GUBA, E. G., \& LINCOLN, Y. S. (1982). "Epistemological and Methodological Bases of Naturalistic Inquiry". Educational Communication and Technology Journal, Volme.30, Issue.4, 233-252.

GUMMESSON, E. (1997), "The New Marketing - Developing Long-term Interactive Relationships," Long Range Planning, 20 (4), 10-20.

GÜLMEZ, M., O. KİTAPÇI. (2003). “İlişki Pazarlamasının Gelişimi ve Yakın Geleceği”, C.Ü. İktisadi ve İdari Bilimler Dergisi, 4(2), 81-89.

HA, H. Y., JANDA, S., \& MUTHALY, S. K. (2010). “A New Understanding of Satisfaction Model in e-re-Purchase Situation”. European Journal of Marketing, Volume.44, Issue.7/8, 997-1016.

HACIEFENDİOĞLU, Ş. (2005). "İlişki Pazarlaması ve Turizm Sektöründe Bir Saha Araştırması”, Kocaeli Üniversitesi Sosyal Bilimler Enstitüsü Dergisi, 2005/1, Sayı: 9, 69-93.

HARKER, M. J. (1999). "Relationship Marketing Defined? An Examination of Current Relationship Marketing Definitions", Marketing Intelligence \& Planning, Vol. 17 Iss: 1, 13 - 20 .

HARUN, N. A., NOOR, M. N. M., \& RAHMAN, A. H. A. (2018). Relationship Marketing in Insurance Industry: A Systematic Analysis of Literatures. In First Padang International Conference On Economics Education, Economics, Business and Management, Accounting and Entrepreneurship (PICEEBA 2018). Atlantis Press.

İLBAN, M.O, DOĞDUBAY, M., GÜRSOY H. (2009). "Otel İşletmelerinde İlişkisel Pazarlama Üzerine Karşılaştırmalı Bir Araştırma", Eskişehir Osmangazi Üniversitesi Sosyal Bilimler Dergisi, Cilt: 10, Say1:2, 117-144.

İSLAMOĞLU, H., ALNIAÇIK, Ü., (2013), Sosyal Bilimlerde Araştırma Yöntemleri, Beta Yayınevi, İstanbul. 
JESRI, P., AHMADİ, F., FATEHIPOOR, M. (2013). "Effects of Relationship Marketing (RM) on Customer Loyalty (Case Study: Mehr Bank, Kermanshah Province, Iran). "Interdisciplinary Journal Of Contemporary Research In Business Vol.4 No.11, 304312 .

JU, Y., BACK, K. J., CHOI, Y., \& LEE, J. S. (2019). "Exploring Airbnb Service Quality Attributes and Their Asymmetric Effects on Customer Satisfaction". International Journal of Hospitality Management, volume.77, 342-352.

KARACA, Ş. (2010). Hizmet Sektöründe İlişki Pazarlaması. Sosyal Ekonomik Araştırmalar Dergisi, 10(19), 441-455.

KARAMAN, D. (2018a). Hizmet Sektöründe İlişskisel Pazarlamanın Önemi: Teorik Bir Araştırma. Bingöl Üniversitesi İktisadi ve İdari Bilimler Fakültesi Dergisi, 2(1), 23-40.

KARAMAN, D. (2018b). Sigortacılık Sektörünün Güncel Sorunlarının Belirlenmesi: Alanya'da Bir Araştırma. Uluslararası Yönetim ve Sosyal Araştırmalar Dergisi, 5(10), 29-37.

KARAMAN, D., (2019). İlişkisel Pazarlama Ekseninde Sürdürülebilir Müşteri Portföyü Oluşturmada Return Modeli: Sigortacılık Sektöründe Araştırma, Pazarlama ve İşletme Araştırmaları, İKSAD Publishing House, ISBN: 978-625-7029-70-4, Ankara, 189219.

KARAMAN, D., ŞAHIN, A., (2019). Sigorta Prim Üretimlerindeki Güncel Değişimlerin Sigorta Acentelerinin Pazar Payına Etkisi ve Öneriler, V. International Congress on Social and Education Sciences (INCSES, December 13-15, 2019), 168-174.

KARIM, I. (2018). "The Influence of Relationship Marketing among Franchisee and Franchisor in Fried Chicken Local Franchise". Saburai International Journal of Social Sciences and Development, Volume.1, Issue.2.

KAUR, H., SOCH, H. (2012). "Validating Antecedents of Customer Loyalty for Indian Cell Phone Users", Vikalpa, Vol. 37, No.4, 47-61.

KILIÇ, H. Ö., ERDOĞAN, B. Z. (2016). Bir İlişkisel Pazarlama Aracı Olarak Bağlamsal Pazarlama: Formdakal Web Sitesi Örneği. İnsan ve Toplum Bilimleri Araştırmaları Dergisi, 5(3), 460-477.

KITAPÇI, O., DORTYOL, I. T., YAMAN, Z., GÜLMEZ, M. (2013). The Paths From Service Quality Dimensions to Customer Loyalty. Management Research Review, 239-255.

KOTLER, P. (1992), "Marketing's New Paradigm: What's Really Happening Out There?" Planning Review, 20 (5), 50-52.

LEVERIN, A., \& LILJANDER, V. (2006). "Does Relationship Marketing Improve Customer Relationship Satisfaction and Loyalty?". International Journal of Bank Marketing, Volume.24, Isuue.4, 232-251. 
LUU, N., NGO, L. V., \& CADEAUX, J. (2018). Value synergy and value asymmetry in relationship marketing programs. Industrial Marketing Management, 68, 165-176.

MORGAN R. M, HUNT, S.D. (1994). "The Commitment-Trust Theory of Relationship Marketing”, Journal of Marketing, Vol. 58, No. 3 (Jul., 1994), 20-38.

O’MALLEY, L., (2018), Metaphor and Relationship Marketing discourse. In The Routledge Companion to Critical Marketing, Routledge, 259-271.

OLY NDUBİSI, N. (2007). "Relationship Marketing and Customer Loyalty”. Marketing intelligence \& planning, Volume.25, Issue.1, 98-106.

ÖZDEMİ, M., KOÇAK, A. (2012). İlişkisel Pazarlama Çerçevesinde Marka Sadakatinin Oluşumu ve Bir Model Önerisi, Ankara Üniversitesi SBF Dergisi, Cilt 67, No. 2, 2012, 127-156.

ÖZYER, Y. (2012). “Tüketici Karar Verme Stilleri ve Tercih Nedenlerinin Alışveriş Merkezi Sadakatine Etkisi”, Marmara Üniversitesi, Sosyal Bilimler Enstitüsü, Halkla İlişkiler ve Tanıtım Anabilim Dalı, Doktora Tezi, İstanbul.

PALMATIER, R. W., \& STEINHOFF, L. (2019). Relationship Marketing in the Digital Age. Routledge.

PALMATIER, R. W., DANT, R. P., GREWAL, D., \& EVANS, K. R. (2006). "Factors Influencing the Effectiveness of Relationship Marketing: A meta-Analysis". Journal of marketing, Volume.70, Issue.4, 136-153.

PELS, J., COVIELLO, N. E., \& BRODIE, R. J. (2000). Integrating transactional and relational marketing exchange: a pluralistic perspective. Journal of Marketing Theory and Practice, 8(3), 11-20.

PRILUCK, R. (2003). "Relationship Marketing Can Mitigate Product and Service Failures", Journal of Services Marketing, Vol. 17 Iss: 1, 37-52.

SHETH, N. J, PARVATIYAR, A (1995). "Relationship Marketing in Consumer Markets: Antecdents and Consequences" Journal of Academy of Marketing Science, Vol.23, No.4, 255-271.

SKOUMPOPOULOU, D., \& FRANKLIN, B. (2019). Implementing a Customer Relationship Management (CRM) System. In Advanced Methodologies and Technologies in Digital Marketing and Entrepreneurship, IGI Global, 57-69.

SODERLUND, M., ROSENGREN, S. (2008), "Revisiting The Smiling Service Worker and Customer Satisfaction", International Journal of Service Industry Management, Vol. 19, No. 5, 552-574.

SONG, K., KIM, K., \& LEE, S. (2018). "Identifying Promising Technologies Using Patents: A Retrospective Feature Analysis and a Prospective Needs Analysis on Outlier Patents". Technological Forecasting and Social Change, volüme.128, 118-132. 
SOTERIOU, A. C., \& CHASE, R. B. (1998). "Linking the Customer Contact Model to Service Quality”. Journal of Operations Management, volüme.16, Issue4, 495-508.

SUSSKIND, A. M., KACMAR, K. M., \& BORCHGREVINK, C. P. (2018). "The Relationship of Service Providers' Perceptions of Service Climate to Guest Satisfaction, Return Intentions, and Firm Performance”. Cornell Hospitality Quarterly,

TEK, Ö.B., (1999), Pazarlama İlkeleri: Global Yönetimsel Yaklaşım Türkiye Uygulamaları.

THAKUR, R., \& SRIVASTAVA, M. (2014). Adoption readiness, personal innovativeness, perceived risk and usage intention across customer groups for mobile payment services in India. Internet Research, 24(3), 369-392.

TİMUR, N. (2003). Pazarlamada Yeni Gelişmeler ve Uygulamalar. Editör: B. Tenekecioğlu, Pazarlama Yönetimi, Eskişehir: Anadolu Üniversitesi Yayınları, No: 1478.

WIKHAMN, W. (2019). "Innovation, Sustainable HRM and Customer Satisfaction”. International Journal of Hospitality Management, volume.76, 102-110.

YILDIRIM, A., ŞİMŞEK, H., (2005), Sosyal Bilimlerde Nitel Araştırma Yöntemleri, Seçkin Yayınevi, Ankara.

YILMAZ, Ö. (2016). Bankacılıkta İlişkisel Pazarlama Faaliyetlerinin, Tekrar Satın Alma Niyeti Üzerine Etkisinde İlişkisel Kalite Algısının Aracılık Rolü Üzerine Bir Araştırma. Business \& Management Studies: An International Journal, 4(2), 142-161.

YURDAKUL, M. (2007). “İlişkisel Pazarlama Anlayışında Müşteri Sadakati Olgusunun Ayrıntılı Bir Şekilde Analizi”, Dumlupınar Üniversitesi, Sosyal Bilimler Enstitüsü Dergisi, Say1:17, 268-287.

YURDAKUL, M., DALKILIÇ, N., (2006), “İlişkisel Pazarlama Anlayışının Sigorta Müşterilerinin Bağlılığı Üzerindeki Etkisi”, Dumlupınar Üniversitesi Sosyal Bilimler Dergisi, S.16, 255-270.

YÜRÜK, P., KAYAPINAR, Ö., (2016), “İlişki Pazarlaması Bileşenleri ile İmaj ve Müşteri Sadakati Arasındaki İlişkilerin İncelenmesine Yönelik Bir Uygulama”, Balkan ve Yakın Doğu Sosyal Bilimler Dergisi, 2, 100-110.

ZHANG, J. Z., WATSON IV, G. F., PALMATIER, R. W., \& DANT, R. P. (2016). Dynamic relationship marketing. Journal of Marketing, 80(5), 53-75.

ZHU, D. H., ZHANG, Z. J., CHANG, Y. P., \& LIANG, S. (2019). “Good Discounts Earn Good Reviews in Return? Effects of Price Promotion on Online Restaurant Reviews". International Journal of Hospitality Management, Volume.77, 178-186. 